http://ejournal.upi.edu/index.php/jaz - e-mail: jurnal.zonasi@gmail.com dan jurnal_zonasi@upi.edu doi.org/10.17509/jaz.v3i3.27895

\title{
PENERAPAN KONSEP "NEW NORMAL" PADA DESAIN SIRKULASI DAN SIGNAGE PUSAT PERBELANJAAN DI KAWASAN KUTA, BALI. STUDI KASUS: BEACHWALK SHOPPING CENTER
}

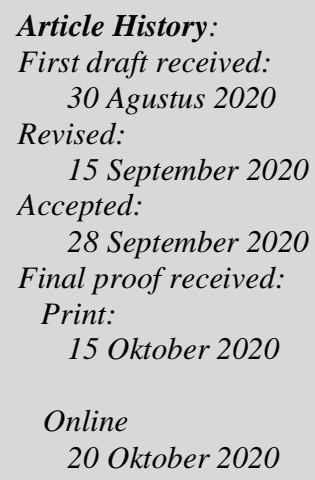

\author{
A.A. Gd. Tugus Hadi Iswara A. $M^{1}$ \\ I Gusti Ayu Canny Utami ${ }^{2}$ \\ Ni Wayan Ardiarani Utami ${ }^{3}$ \\ 1,2,3 Institut Desain dan Bisnis Bali, Denpasar, Indonesia \\ Jalan Tukad Batanghari no.29 Panjer, Denpasar Selatan \\ Email: aatugus@gmail.com \\ canny@std-bali.ac.id \\ ardiarani.utami@std-bali.ac.id
}

Abstract: The "New Normal" concept has a significant impact on social activities and inavitable change in both interior and exterior design especially in term of signage and sirculation. Shopping center becoming one of the most affected areas as its a place used by a lot of people. In this case Beachwalk Shopping Center in response to the COVID-19 pandemic have changed their existing design to prevent the spread of the virus. According to Lawrence K. Frank "Sign (signge) is a message or information that appears consecutively or regularly in relation to signs that are important and generate responses in humans. Signage as a basic element which has the main function as a communication between humans in a building or environment. The research method used is descriptive qualitative method. Qualitative methods aim to understand the phenomena that occur and are experienced by research subjects, related to perceptions, behavior and actions as a whole and use descriptions in the form of words and language for a natural purpose. This method is used to explain the "New Normal" concept application in Beachwalk Shopping Center circulation and signage design in accordance with the health protocol issued by the Ministry of Health of the Republic of Indonesia through Circular Number HK.02.01 / MENKES / 335/2020 concerning the Protocol for the Prevention of Covid-Transmission. The health protocols for managers of business premises, workers and consumers has been carried out well, especially in circulation and signage. It is hoped that the awareness of each individual can reduce the chances of being infected or spreading COVID-19.

Keywords: New Normal, Interior, Signage, Beachwalk Shopping Center

Abstrak: Konsep "New Normal" memberikan dampak yang signifikan terhadap perubahan aktivitas civitas dan tatanan ruang yang ada, baik dalam ranah interior maupun eksterior. Penyesuaian yang dilakukan oleh pusat perbelanjaan Beachwalk Shopping Center menyikapi pandemic COVID-19 merubah tatanan design yang telah ada. Diantaranya dalam hal penerapan elemen sirkulasi (signage) yang digunakan. Menurut Lawrence K. Frank "Sign (signge) adalah pesan atau informasi yang muncul secara berturut-turut atau teratur dalam hubungannya dengan tanda-tanda yang penting dan menimbulkan respon pada manusia. Sebuah sign muncul secara berturut-turut atau teratur, tapi maksud berturutturut atau teratur ini tidak dijelaskan lebih lanjut sehingga untuk saat ini hal itu tidak akan menjadi pertimbangan pengertian sebuah pertanda (sign). Signage sebagai elemen dasar yang memiliki fungsi utama sebagai alat komunikasi antar manusia dalam suatu bangunan atau lingkungan mengandung beberapa elemen penting. Elemen-Elemen ini akan membentuk image atau fisik keseluruhan dari sign yang juga berperan dalam keberhasilan penyampaian informasi yang ingin ditujukan oleh signage tersebut. Selain signage, elemen sirkulasi yang digunakan di Beachwalk Shopping Center ini juga menggunakan pola mall dan dalam unit took menggunakan pola banyak koridor. Metode Penelitian yang digunakan adalah metode kualitatif deskriptif. Metode kualitatif bertujuan untuk memahami fenomena yang terjadi dan dialami oleh subjek penelitian, terkait dengan persepsi, perilaku dan 
tindakan secara keseluruhan serta menggunakan deskripsi dalam bentuk kata-kata dan Bahasa untuk suatu tujuan yang alamiah. Metode ini digunakan untuk menjelaskan konsep "New Normal" yang diterapkan pada desain sirkulasi dan signage Beachwalk Shopping Center sesuai dengan protokol kesehatan yang telah dikeluarkan oleh Kementerian Kesehatan Republik Indonesia melalui Surat Edaran Nomor HK.02.01/MENKES/335/2020 tentang Protokol PencegahanPenularan Covid-19 di Tempat Kerja Sektor Jasa dan Pedagangan (Area Publik) Dalam Mendukung Keberlangsungan Usaha. Berdasarkan hasil kajian, maka dapat diketahui bahwa desain sirkulasi dan signage pada Beachwalk Shopping Center telah memenuhi protokol kesehatan sesuai dengan Surat Edaran Kementerian KesehatanNomor HK.02.01/MENKES/335/2020 tentang Protokol Pencegahan Penularan Covid-19 di Tempat Kerja Sektor Jasa dan Pedagangan (Area Publik) Dalam Mendukung Keberlangsungan Usaha dalam masa "New Normal". Penerapan protokol kesehatan untuk pengelola tempat usaha, pekerja dan konsumen telah terlaksana dengan baik terutama pada sirkulasi dan signage. Kesadaran tiap individu diharapkan dapat lebih memaksimalkan penerapan prokol kesehatan ini.

Kata Kunci: New Normal, Interior, Signage, Beachwalk Shopping Center

\section{Pendahuluan}

Gugus Tugas Percepatan Penanganan COVID-19 Republik Indonesia mencatat adanya 149.408 kasus terkonfirmasi positif covid-19 di Indonesia hingga tanggal 21 Agustus 2020 (G. T. P. P. C.-19 R. Indonesia, 2020). Dari angka tersebut, terdapat 39.917 orang yang masih dalam perawatan dan $68.9 \%$ telah terkonfirmasi sembuh. Angka kesembuhan yang hampir mencapai angka 70\%, menyebabkan Pemerintah Indonesia menetapkan kondisi kenormalan baru/ New Normal pada beberapa aspek kehidupan masyarakat.

Konsep new normal memberikan dampak yang signifikan terhadap perubahan aktivitas civitas dan tatanan ruang yang ada baik dalam ranah interior maupun eksterior. Berdasarkan Surat Edaran Nomor HK.02.01/MENKES/335/2020 tentang Protokol Pencegahan Penularan Covid-19 di Tempat Kerja Sektor Jasa dan Pedagangan (Area Publik) Dalam Mendukung Keberlangsungan Usaha (M. K. R. Indonesia, 2020) dengan sangat jelas menyebutkan perihal penyesuaian design ruang publik terkait perubahan prilaku masyarakat akibat pandemi. Pada Surat Edaran tersebut memuat beberapa protokol kesehatan bagi pengurus atau pengelola tempat kerja/ pelaku usaha, bagi pekerja, dan bagi konsumen yang secara langsung mengakibatkan penyesuaian design dengan tujuan mencegah penularan COVID -19.

Pengurus atau pengelola tempat kerja/pelaku usaha pada sektor jasa dan perdagangan (Area Publik) diwajibkan untuk melakukan pembersihan dan disinfeksi secara berkala di area kerja dan area publik (mendisinfeksi fasilitas umum yang sering disentuh publik setiap 4 jam sekali), menyediakan fasilitas cuci tangan yang memadai dan mudah diakses oleh pekerja dan konsumen/pelaku usaha, melakukan pengecekan suhu badan bagi seluruh pekerja sebelum mulai bekerja dan konsumen/pelaku usaha di pintu masuk. Beberapa peraturan yang berdampak pada perubahan fisik design area publik diantaranya, memasang media informasi untuk mengingatkan pekerja, pelaku usaha, pelanggan/konsumen dan pengunjung agar mengikuti ketentuan pembatasan jarak fisik dan mencuci tangan pakai sabun dengan air mengalir/handsanitizer serta kedisplinan menggunakan masker, melakukan pembatasan jarak fisik minimal 1 meter, memberikan tanda khusus yang ditempatkan di lantai area padat pekerja seperti ruang ganti, lift, dan area lain sebagai pembatas jarak antar pekerja, pengaturan meja kerja, tempat duduk dengan jarak minimal 1 meter, melakukan upaya untuk meminimalkan kontak dengan pelanggan, menggunakan pembatas/partisi (misalnya flexy glass) di meja atau konter sebagai perlindungan tambahan untuk pekerja (kasir, customer service dan lain-lain), mendorong penggunaan metode pembayaran non tunai (tanpa kontak dan tanpa alat bersama). Mencegah kerumunan pelanggan, dilakukan dengan cara: menerapkan sistem antrian di pintu masuk dan menjaga jarak minimal 1 meter, memberikan tanda di lantai untuk memfasilitasi kepatuhan jarak fisik, khususnya di daerah yang paling ramai, seperti kasir dan custosmer service. Serta, menetapkan jam layanan, sesuai dengan kebijakan yang ditetapkan pemerintah daerah setempat sesuai ketentuan peraturan perundang- undangan. Selain surat edaran tersebut, World Health Organization juga mengeluarkan panduan penerapan "New Normal" yang terdiri dari enam kriteria. Salah satu kriteria yaitu penetapan langkah-langkah pencegahan. Langkah-langkah pencegahan meliputi penerapan jaga jarak secara fisik, ketersediaan fasilitas untuk mencuci tangan dan penerapan etika pernafasan yang diterapkan dengan minimal penggunaan masker (WHO, 2020) 
Pemerintah Provinsi Bali memutuskan untuk menerapkan "Tatanan Kehidupan Era Baru/ New Normal" dalam tiga tahapan. Tahapan pertama dimulai dari tanggal 9 Juli 2020 untuk masyarakat lokal Bali. Tahapan kedua telah dimulai dari tanggal 31 Juli 2020 pada sektor pariwisata untuk wisatawan Nusantara. Tahap ketiga akan dimulai, apabila kondisi pertama dan kedua lancar, yaitu pada tanggal 11 September 2020, Bali akan dibuka untuk wisatawan mancanegara (Bali, 2020). Kondisi Provinsi Bali yang telah memasuki tahapan ke-2 "New Normal" menyebabkan banyak pihak berbenah untuk menyesuaikan kondisi ini. Beberapa pihak yang menerapkan kondisi "New Normal" adalah pusat-pusat perbelanjaan, salah satunya adalah Beachwalk Shopping Center sebagai salah satu pusat perbelanjaan terbesar di Provinsi Bali.

Penyesuaian yang dilakukan oleh pusat perbelanjaan Beachwalk Shopping Center COVID-19 merubah tatanan design yang telah ada, diantaranya dalam hal penerapan elemen sirkulasi (signage) yang digunakan. Menurut Lawrence K. Frank (Pynkyawati, Aripin, Iliyasa, \& Ningsih, 2014) "Sign (signge) adalah pesan atau informasi yang muncul secara berturut-turut atau teratur dalam hubungannya dengan tanda-tanda yang penting dan menimbulkan respon pada manunsia". Sebuah sign muncul secara berturutturut atau teratur, tapi maksud berturut-turut atau teratur ini tidak dijelaskan lebih lanjut sehingga untuk saat ini hal itu tidak akan menjadi pertimbangan pengertian sebuah pertanda (sign). Signage sebagai elemen dasar yang memiliki fungsi utama sebagai alat komunikasi antar manusia dalam suatu bangunan atau lingkungan mengandung beberapa elemen penting. Elemen-Elemen ini akan membentuk image atau fisik keseluruhan dari sign yang juga berperan dalam keberhasilan penyampaian informasi yang ingin ditujukan oleh signage tersebut. Selain signage, elemen sirkulasi yang digunakan di Beachwalk Shopping Center ini juga menggunakan pola mall dan dalam unit toko menggunakan pola banyak koridor. Pola ini biasanya digunakan dalam pusat perbelanjaan agar tidak terjadi kerumitan dan pengumpulan pengunjung pada suatu tempat saja (Hapsari, 2014)

Artikel ini bertujuan untuk mengkaji design sirkulasi dan signage pada Beachwalk Shopping Center dalam menerapkan konsep "New Normal" sesuai dengan Surat Edaran Kementerian Kesehatan Nomor HK.02.01/MENKES/335/2020 tentang Protokol Pencegahan Penularan Covid-19 di Tempat Kerja Sektor Jasa dan Pedagangan (Area Publik) Dalam Mendukung Keberlangsungan Usaha

\section{Metode Penelitian}

Metode Penelitian yang digunakan adalah metode kualitatif deskriptif. Metode kualitatif bertujuan untuk memahami fenomena yang terjadi dan dialami oleh subjek penelitian, terkait dengan persepsi, perilaku dan tindakan secara keseluruhan serta menggunakan deskripsi dalam bentuk kata-kata dan bahasa untuk suatu tujuan yang alamiah (Moleong, 2017). Metode ini digunakan untuk menjelaskan konsep "New Normal" yang diterapkan pada desain sirkulasi dan signage Beachwalk Shopping Center sesuai dengan protokol kesehatan yang telah dikeluarkan oleh Kementerian Kesehatan Republik Indonesia melalui Surat Edaran Nomor HK.02.01/MENKES/335/2020 tentang Protokol Pencegahan Penularan Covid-19 di Tempat Kerja Sektor Jasa dan Pedagangan (Area Publik) Dalam Mendukung Keberlangsungan Usaha.

\section{Hasil dan Pembahasan}

\subsection{Analisis Pola Sirkulasi Ruang}

Perubahan pola sirkulasi yang terlihat dari masa sebelum pandemi, Beachwalk Shopping Mall menerapkan sistem sirkulasi terbuka sedangkan setelah adanya pandemi Covid-19 sirkulasi berubah menjadi sistem sirkulasi tertutup. Selain itu juga, pada bagian unit toko, yang sebelumnya menggunakan pola banyak ruang, sekarang berubah menjadi pola linier, untuk meminimalkan adanya pertemuan antara pengunjung. Hal ini dapat dilhat dari adanya penempatan etalase produk serta beberapa signage yang mengatur hal tersebut. 


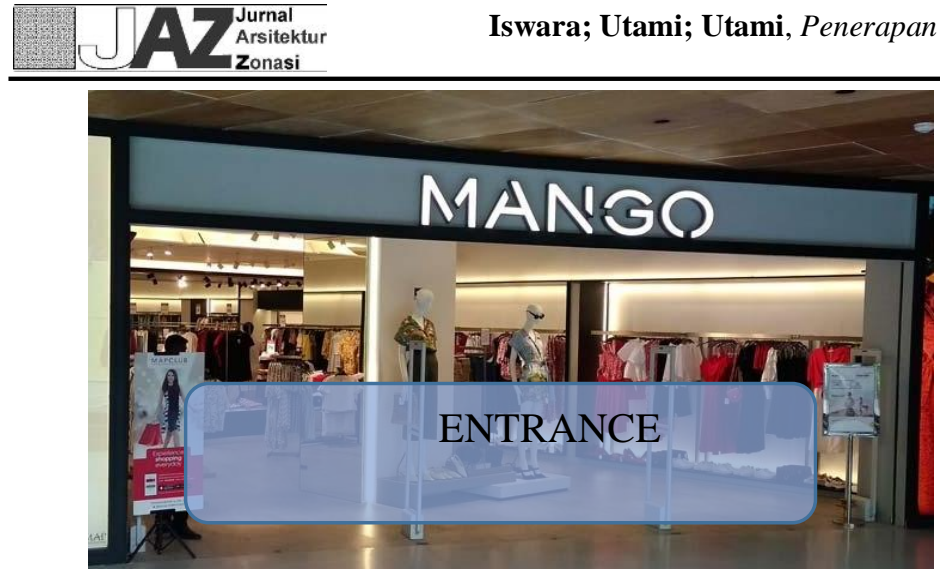

Gambar 1. Entrance sebelum "New Normal"

(Sumber: www.google.com/beachwalk/mango/, 2020)

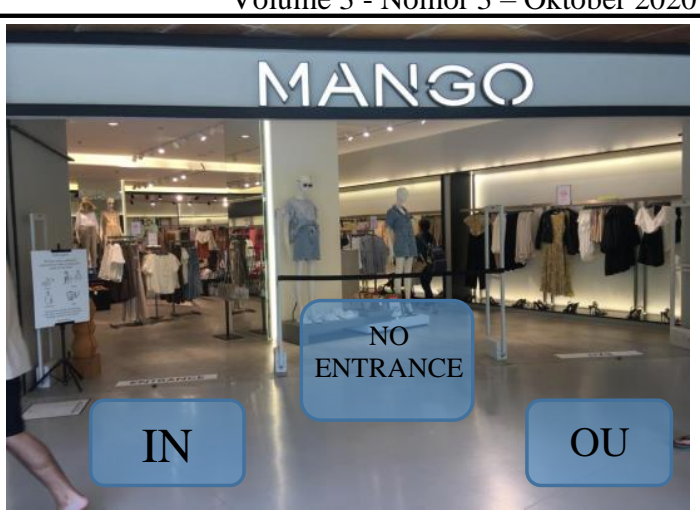

Gambar 2. Entrance setelah "New Normal" (Sumber: Utami, 2020)

Pada gambar 1, untuk memasuki unit toko, dapat masuk dari bagian depan toko dimana saja, sedangkan setelah adanya penerapan konsep "New Normal", ada pembagian dalam memasuki unit toko, biasanya satu bagian untuk masuk, dan bagian sebelahnya untuk keluar, serta ada ruang tengah yang membatasi jalur keluar masuk yang ditunjukan pada gambar 2. Hal ini juga untuk memenuhi protokol kesehatan yang dikeluarkan oleh Menteri Kesehatan Republik Indonesia, yang mana mengatur untuk menjaga jarak minimal 1 meter dan memberikan tanda di lantai untuk memfasilitasi kepatuhan jarak fisik,
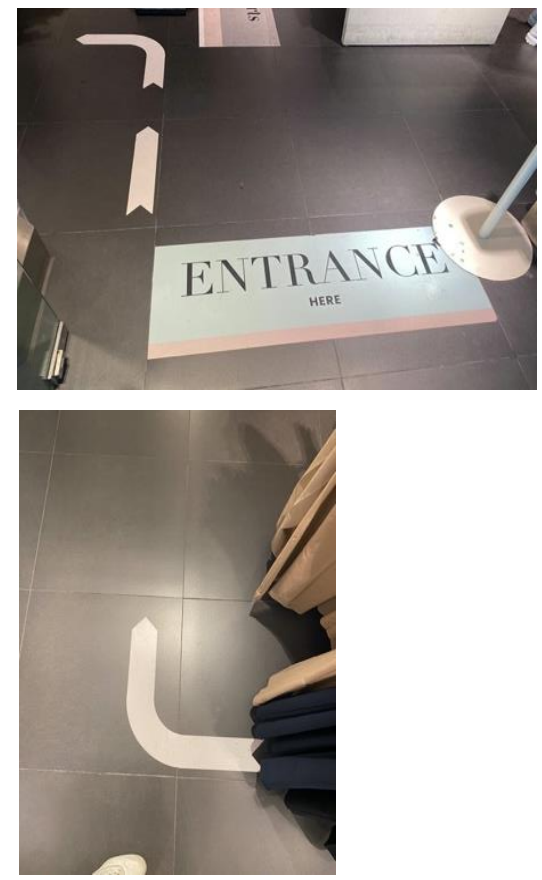
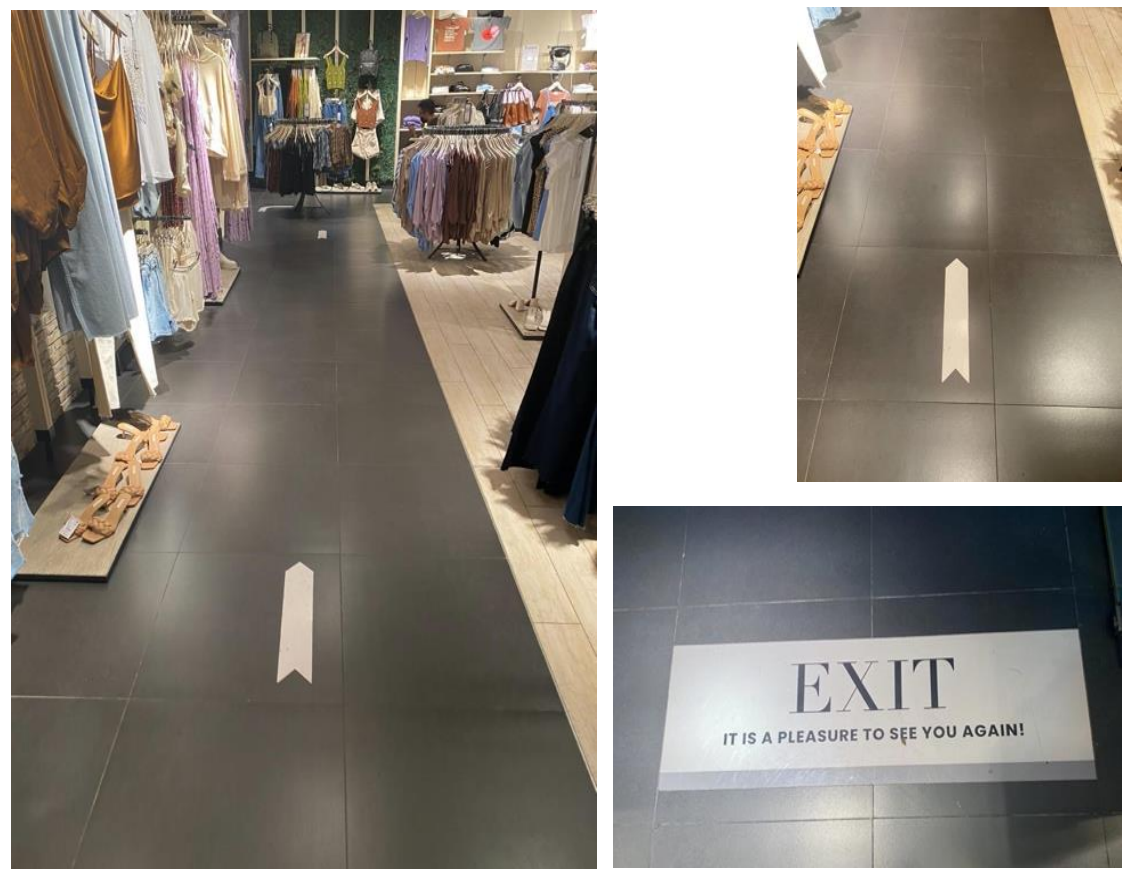

Gambar 3. Pola sirkulasi dalam unit toko setelah "New Normal"

(Sumber: Utami, 2020)

Pola sirkulasi ruang di bagian utama Beachwalk Shopping Center, sebelum dan setelah pendemi masih tetap berupa pola linier, hanya ada penambahan pada elemen petanda (signage) setelah penerapan konsep "New Normal. Penambahan elemen petanda ini untuk memenuhi protokol kesehatan, yaitu memberikan tanda di lantai untuk memfasilitasi kepatuhan jarak fisik, sehingga diharapkan pengunjung yang datang akan tetap mematuhi protokol kesehatan. 

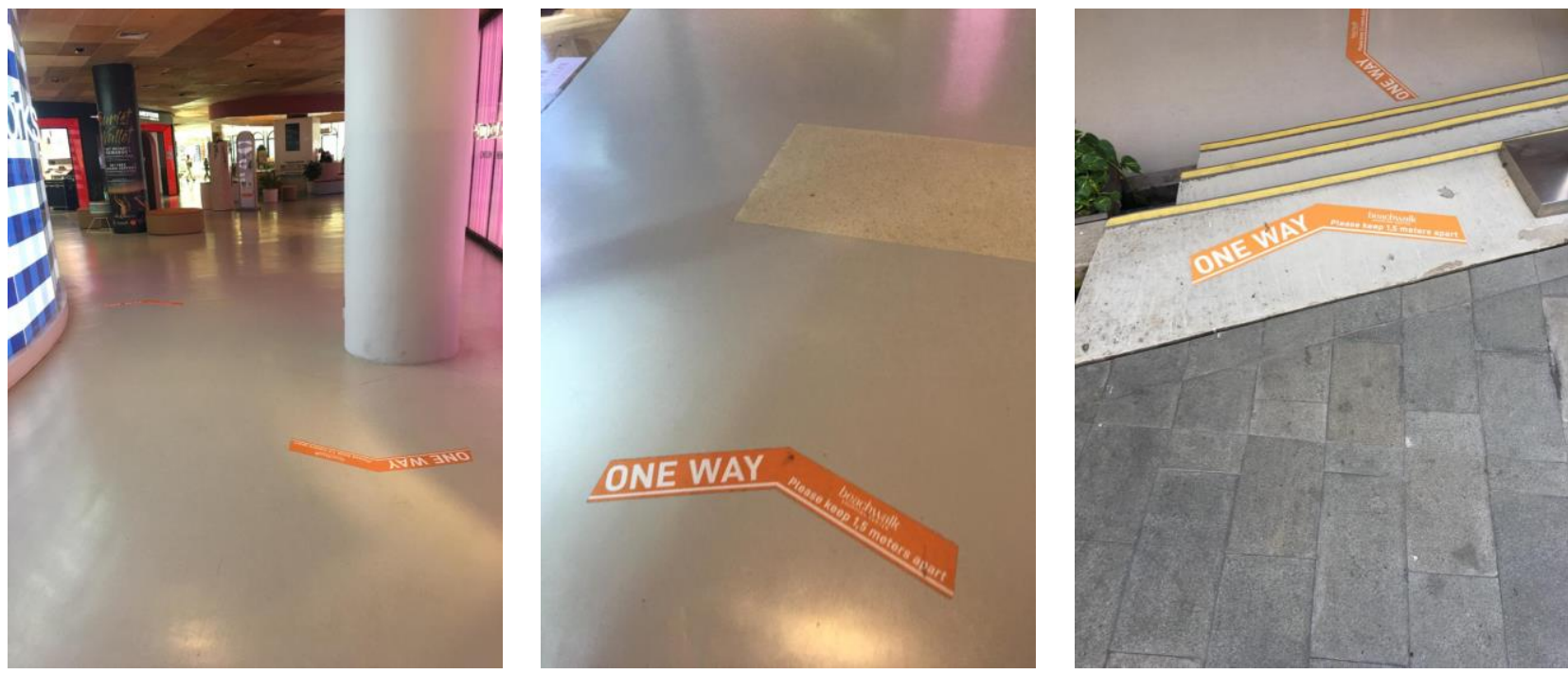

Gambar 4. Pola sirkulasi di bagian utama Beachwalk Shopping Center setelah "New Normal" Sumber: Utami, 2020

\subsection{Analisis Penerapan Elemen Petanda Dalam Bangunan (Signage) \\ 3.2.1 Penempatan sistem petanda (signage) Petunjuk Arah}

Penggunaan signage sebagai alat untuk menyampaikan informasi kepada orang lain harus mempertimbangkan berbagai aspek yaitu visibilitas, redibilitas, legibilitas yang membuat keberadaannya dapat disadari dan dapat berfungsi dengan baik. Posisi penempatan signage dapat dilihat pada hamper seluruh interior bangunan, dari pintu masuk hingga kedalam bangunan. Letaknya pun sangat mudah untuk dilihat, karena terletak di posisi yang strategis.

Pada entrance ke bangunan, terdapat protokol kesehatan yang harus dipatuhi, yaitu antrian untuk memasuki bangunan, check in pada aplikasi, pemeriksaan suhu, dan penggunaan hand sanitizer. Signage terlihat sangat jelas dan berjumlah cukup banyak pada beberapa tempat, sehingga meminimalkan untuk tidak terlihat, selain itu, penempatan penjaga pada entrance juga memaksimalkan penggunaan dari signage.

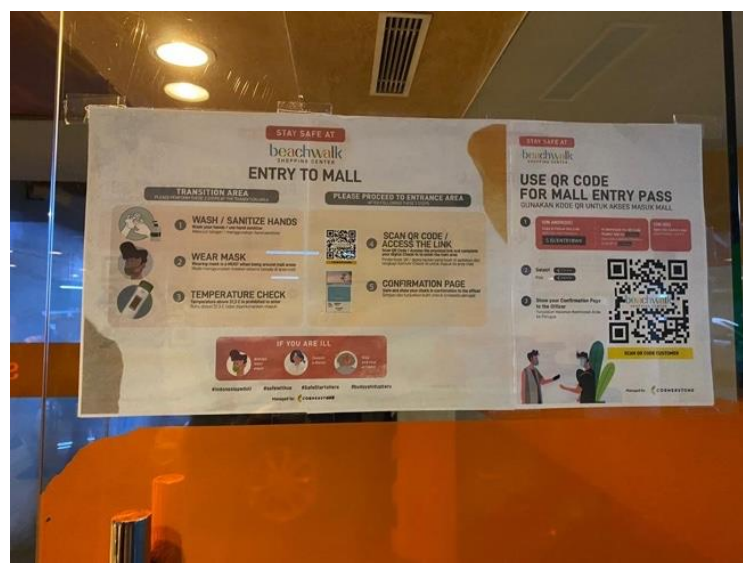

Gambar 5. Signage untuk entrance dan check ini pada aplikasi ke Beachwalk Sumber: Utami, 2020

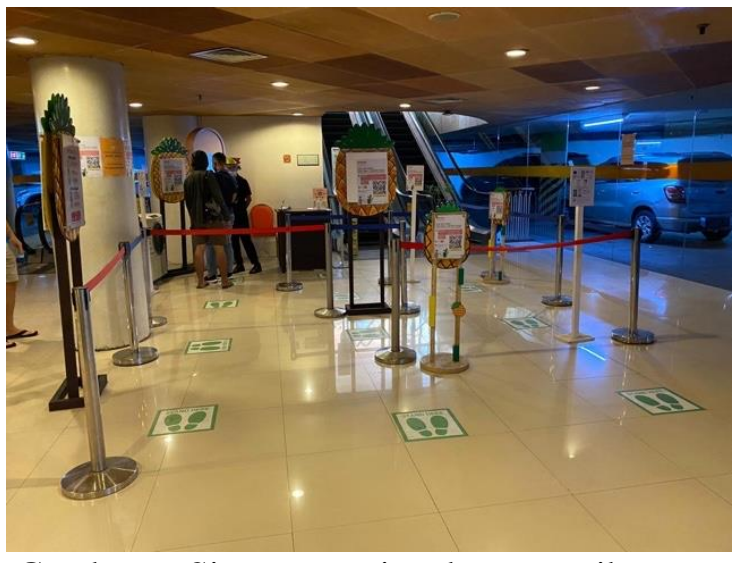

Gambar 6. Signage antrian dan pemeriksaan suhu tubuh.

Sumber: Utami, 2020

Pada interior bangunan Beachwalk Shopping Center, penempatan signage untuk petunjuk arah dapat dilihat pada bagian lantai, dinding maupun pintu masuk unit toko. Adanya signage ini dapat terus mengingatkan pengunjung Beachwalk Shopping Center untuk tetap menjaga protokol kesehatan karena secara tidak langsung terus membaca signage yanga ada. 

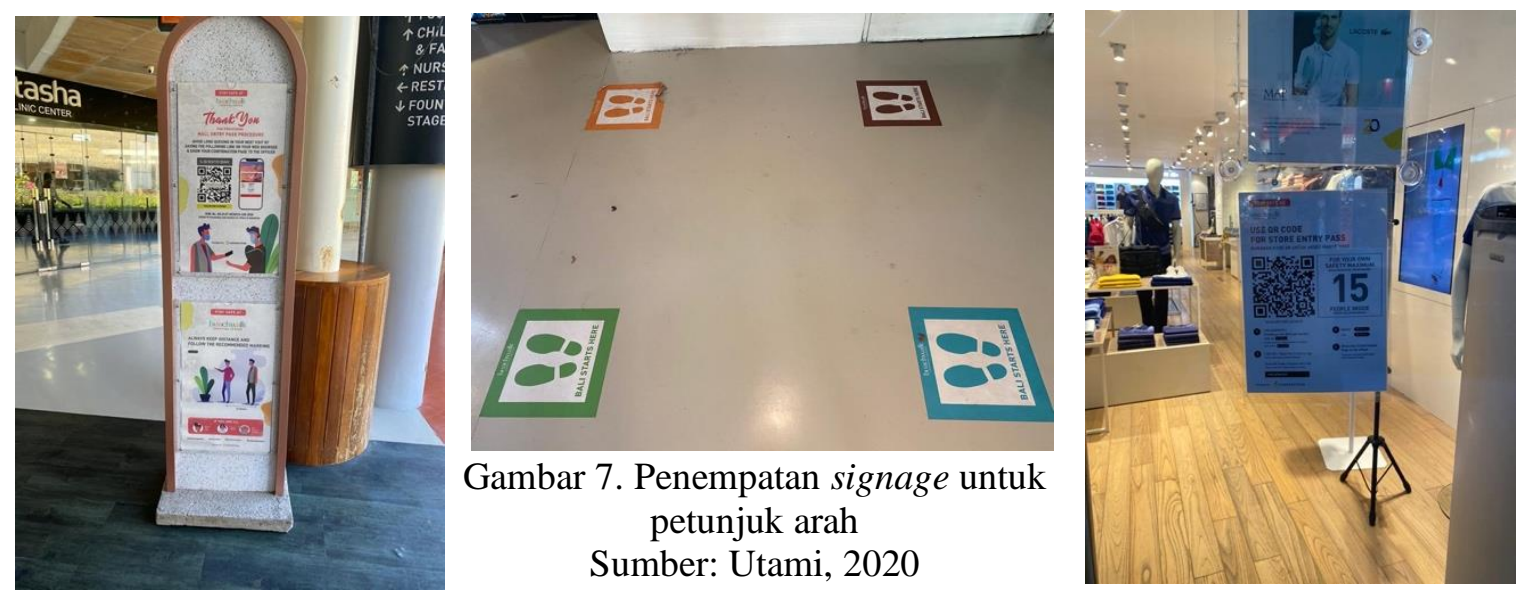

\subsubsection{Penggunaan Elemen Signage pada Sirkulasi Bangunan}

Elemen signage yang diletakan pada sirkulasi bangunan berfungsi sebagai konsep "New Normal" dalam berjalan-jalan pada pusat perbelanjaan di masa pendemi Covid-19. Signage dapat ditemukan pada sirkulasi vertikal dan horizontal. Sirkulasi vertikal dapat dilihat pada eskalator dan lift, dimana banyak signage ditempatkan sebagai informasi/pengumuman ataupun tempat berdiri.

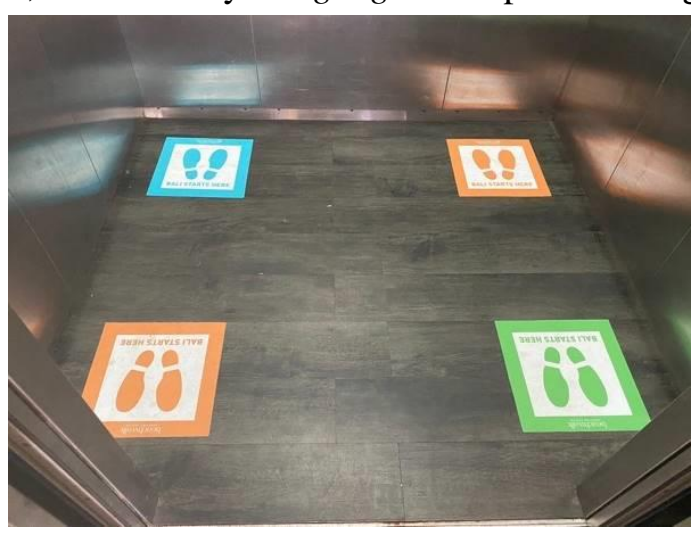

Gambar 8. Signage pada lift Sumber: Utami, 2020

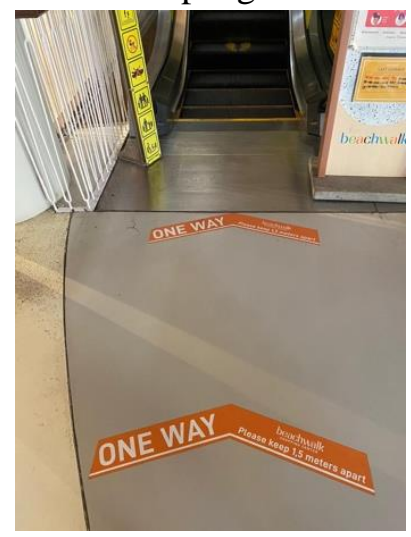

Gambar 9. Signage pada eskalator Sumber: Utami, 2020

Sirkulasi horizontal terlihat pada setiap lantai yang ada pada bangunan, hampir sebagian besar berisi signage. Signage berupa petunjuk arah maupun petunjuk jarak yang sebaiknya dijaga untuk mengikuti protokol kesehatan. Di tiap unit toko juga terdapat signage yang dipasang oleh masingmasing toko sesuai dengan kreatifitas masing-masing tapi dengan tetap memenuhi standar protokol kesehatan.
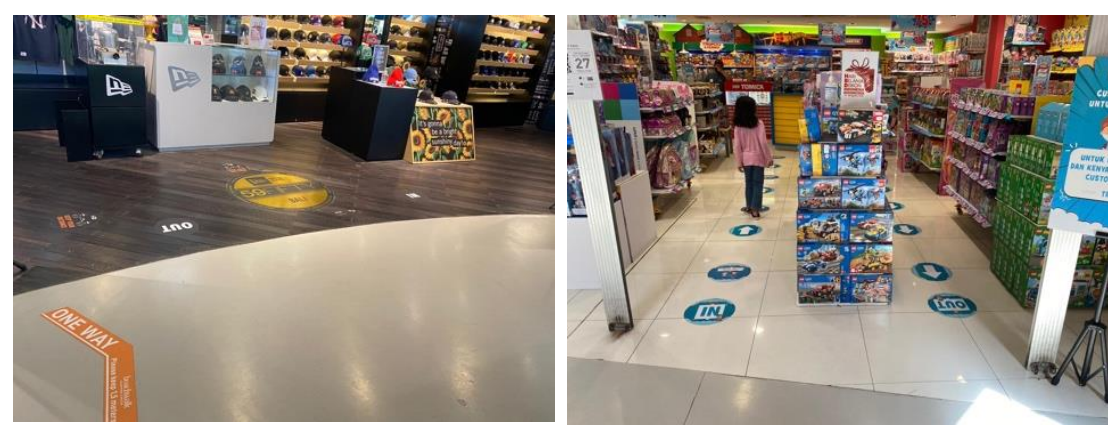

Gambar 10. Signage pada sirkulasi horizontal Sumber: Utami, 2020

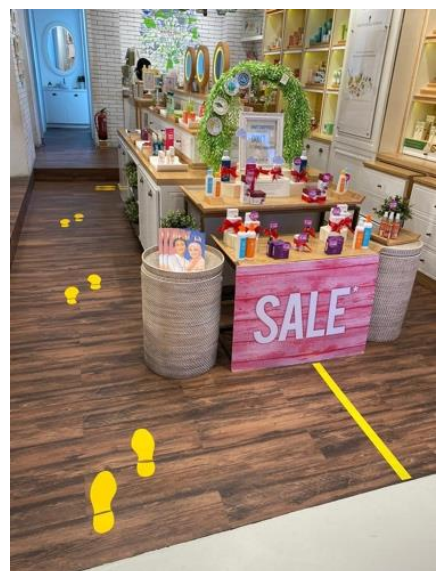




\subsubsection{Penggunaan Elemen Signage sebagai Protokol New Normal}

Penerapan jaga jarak dapat dilihat dari berbagai signage yang ada. Signage berupa gambar kaki sebagai tanda untuk tempat berdiri ataupun garis batas sebagai jarak antrean. Penempatan signage ini ada pada eskalator, antrean menuju "Fitting Room", antrean menuju ke kasir, etalase produk dan tempat duduk.

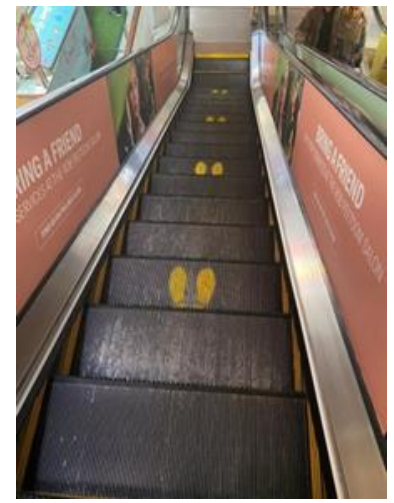

Gambar 11. Signage jarak berdiri pada eskalator Sumber: Utami, 2020

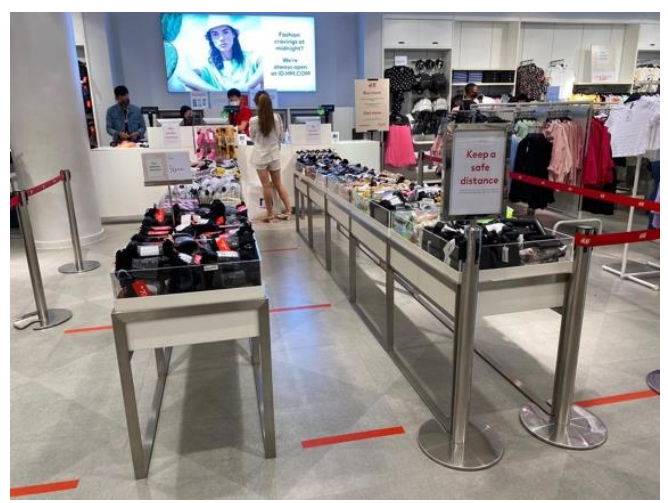

Gambar 12. Signage antrean pada kasir Sumber: Utami, 2020

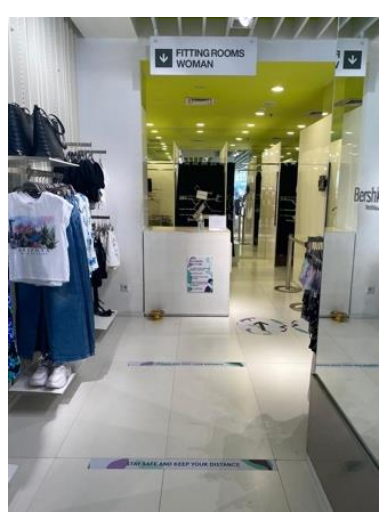

Gambar 13. Signage antrean pada "Fitting Room" Sumber: Utami, 2020

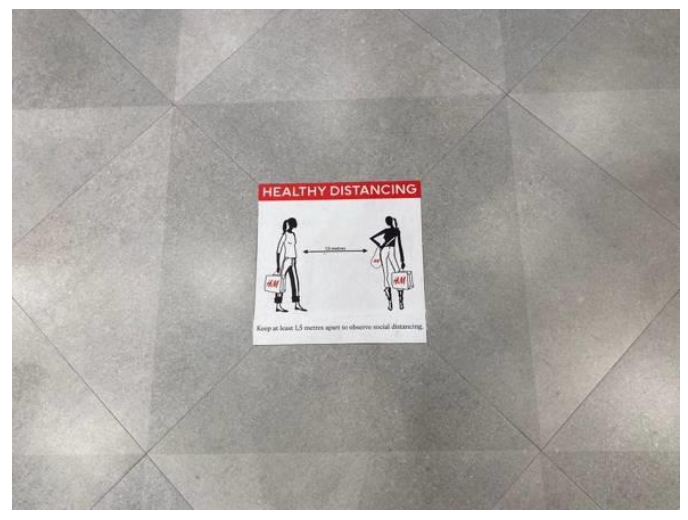

Gambar 14. Signage pengaturan jarak aman Sumber: Utami, 2020

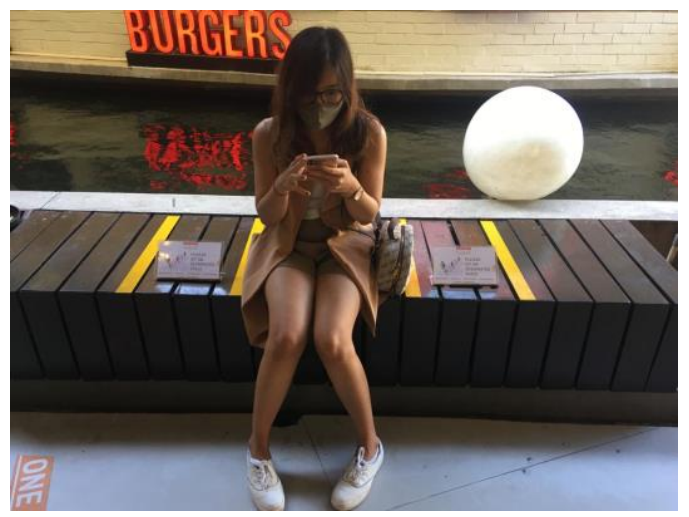

Gambar 15. Signage pada tempat duduk Sumber: Utami, 2020

Pada Beachwalk Shopping Center juga terdapat berbagai signage yang selain bersifat untuk mengatur ada juga yang bersifat memberikan semangat ataupun pengingat untuk tetap memperhatikan protokol kesehatan. Diantaranya adalah himbauan serta anjuran untuk selalu memperhatikan jarak diri dan penggunakaan masker. Penempatan signage ini ada pada beberapa tempat yaitu di lantai, pintu masuk unit toko dan beberapa bagian peralihan ruang.

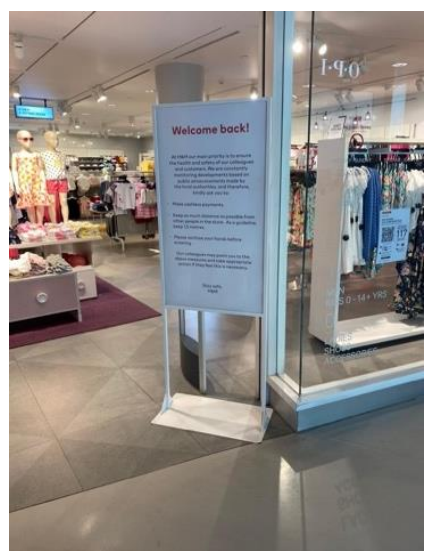

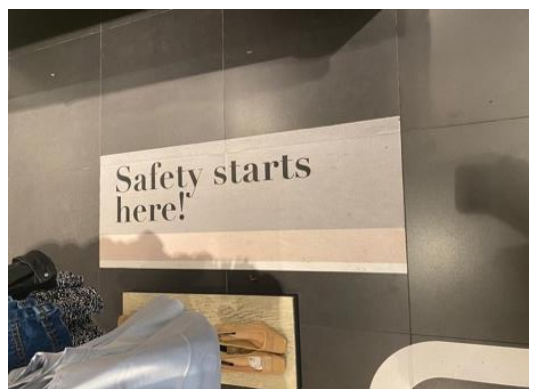

Gambar 16. Signage sebagai pengingat atau anjuran protokol kesehatan Sumber: Utami, 2020

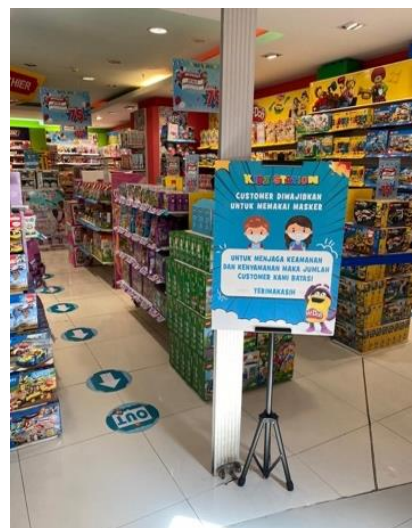


Protokol kesehatan untuk selalu menggunakan hand sanitizer ataupun sabun cuci juga diterapkan dalam tempat ini. Selain pada entrance bangunan, penempatan hand sanitizer juga ada pada entrance setiap unit toko, dan entrance lift. Jadi diharapkan untuk semua konsumen yang akan memasuki unit toko, akan terjaga kebersihan tangan apabila masuk ke dalam unit toko, serta tetap terjaga kebersihan tangan, walaupun telah mememcet pintu lift.
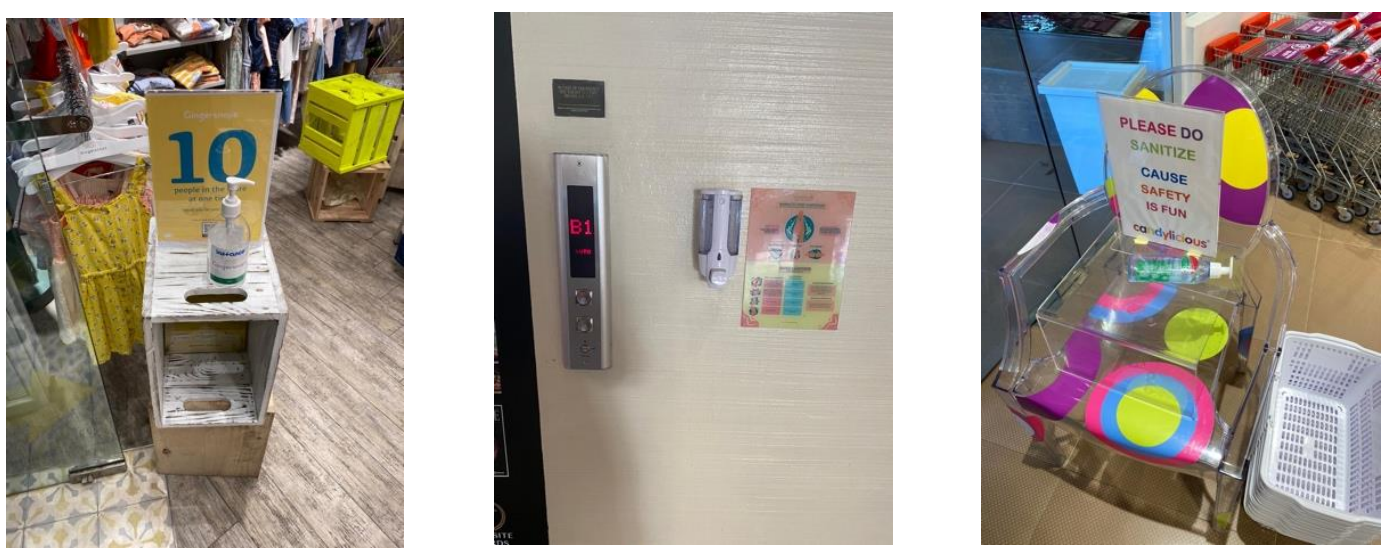

Gambar 17. Signage hand sanitizer pada entrance unit toko dan lift

Sumber: Utami, 2020

Pengurangan kontak langsung antara penjual dan konsumen dapat dilihat pada signage yang terletak di kasir, yaitu adanya papan kaca dengan signage untuk tetap menjaga protokol kesehatan. Papan kaca ini dapat meminimalkan terjadinya penularan virus Covid-19 walaupun antara konsumen dan penjual terjadi kontak fisik yang tidak dapat dihindari.
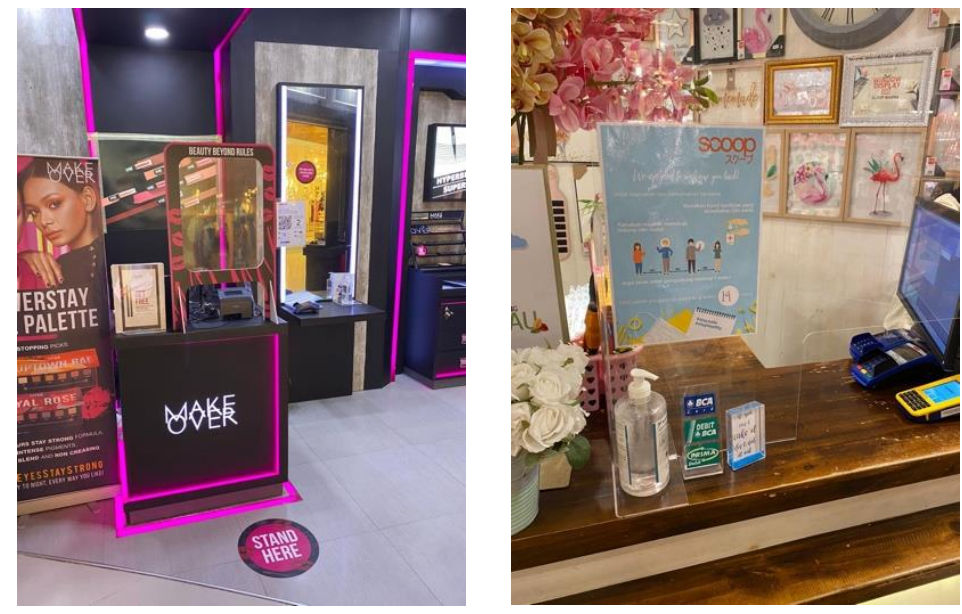

Gambar 18. Signage pada papan kaca kasir Sumber: Utami, 2020

\section{Kesimpulan}

Desain sirkulasi dan signage pada Beachwalk Shopping Center telah memenuhi protokol kesehatan sesuai dengan Surat Edaran Kementerian Kesehatan Nomor HK.02.01/MENKES/335/2020 tentang Protokol Pencegahan Penularan Covid-19 di Tempat Kerja Sektor Jasa dan Pedagangan (Area Publik) Dalam Mendukung Keberlangsungan Usaha dalam masa "New Normal". Penerapan protokol kesehatan untuk pengelola tempat usaha, pekerja dan konsumen telah terlaksana dengan baik terutama pada sirkulasi dan signage. Kesadaran tiap individu diharapkan dapat lebih memaksimalkan penerapan prokol kesehatan ini.

Untuk penelitian selanjutnya, dapat dilakukan dengan melihat perubahan perilaku individu dalam merespon konsep "New Normal" pada desain pola sirkulasi dan signage pada pusat perbelanjaan. Penelitian selanjutnya dapat melihat keberhasilan dari penerapan konsep "New Normal" ini. 


\section{Referensi}

Bali, P. P. (2020). Pulihkan Ekonomi Bali, Gubernur Resmikan Tatanan Kehidupan Era Baru di Pantai Pandawa - Pemerintah Provinsi Bali. Retrieved August 21, 2020, from https://www.baliprov.go.id/web/pulihkan-ekonomi-bali-gubernur-resmikan-tatanan-kehidupan-erabaru-di-pantai-pandawa/

Hapsari, Ade S. helen. (2014). Pengaruh Pola Sirkulasi Pusat Perbelanjaan Mall Terhadap Pola Penyebearan Pengunjung. Jurnal Desain Konstruksi, 13(2), 46-57.

Indonesia, G. T. P. P. C.-19 R. (2020). Peta Sebaran | Gugus Tugas Percepatan Penanganan COVID-19. Retrieved August 21, 2020, from https://covid19.go.id/peta-sebaran

Indonesia, M. K. R. Surat Edaran Nomor HK.02.01/MENKES/335/2020 Tentang Protokol Pencegahan COVID-19 di Tempat Kerja Sektor Jasa dan Perdagangan (Area Publik) Dalam Mendukung Keberlangsungan Usaha. , Pub. L. No. HK.02.01/MENKES/335/2020, 1 (2020).

Moleong, L. J. (2017). Metodologi Penelitian Kualitatif Edisi Revisi (37i ed.). Bandung: PT. Remaja Rosdakarya.

Pynkyawati, T., Aripin, S., Iliyasa, E. R. I., \& Ningsih, L. Y. (2014). Kajian Efisiensi Desain Sirkulasi pada Fungsi Bangunan Mall Dan Hotel BTC. Jurnal Reka Karsa, 2(1), 1-12.

WHO. (2020). Coronavirus Disease Situation Report World Health Organization. World Health Organization, 19(May), 1-17. 